NOTES to do:

Write to BMC re. figure re-use

NHM Library for figure from Dodoens/Matthioli

Mindy for map

\title{
The tomato (Solanum lycopersicum L., Solanaceae) and its botanical relatives
}

Sandra Knapp and Iris E. Peralta

Department of Life Sciences, Natural History Museum, Cromwell Road, London SW7 5BD, United

Kingdom; Departmento de Agronomía, Universidad Nacional del Cuyo, Almirante Brown 500, 5505

Chacras de Coria \& IADIZA- CCT CONICET Mendoza, Argentina.

\section{Introduction}

The cultivated tomato, Solanum lycopersicum L., belongs to the diverse family Solanaceae, which includes more than 3000 species, occupying a wide variety of habitats (Knapp 2002). The Solanaceae contain many species of economic use, both for food (tomatoes, potatoes, peppers and eggplants), medicines (deadly nightshade, henbane, datura) and ornamental purposes (petunias). Solanum lycopersicum was previously recognised as Lycopersicon esculentum Mill., but data from both morphology and molecular sequences support its inclusion in the large genus Solanum L., and a revised new nomenclature has resulted (Peralta and Spooner 2001; Spooner et al. 2005; Peralta and Spooner 2005; Peralta et al. 2006; Peralta et al. 2008). Morphological characters, phylogenetic relationships, and geographical distribution have demonstrated that tomatoes (Solanum sect. Lycopersicon (Mill.) Wettst.) and their immediate outgroups in Solanum sect. Lycopersicoides (A.Child) Peralta and sect. Juglandifolia (Rydb.) A.Child form a sister clade to potatoes (sect. Petota Dumort.), with Solanum sect. Etuberosum (Buk. \& Kameraz) Child being sister to potatoes + tomatoes (Spooner et al. 1993; Peralta and Spooner 2001; Spooner et al. 2005; Peralta et al. 2008; Rodriguez et al. 2010; Särkinen et al. 2013). Analyses of multiple data sets from a variety of genes unambiguously establish tomatoes to be deeply nested in Solanum (Bohs and Olmstead 1997, 1999; Olmstead and Palmer 1997; Olmstead et al. 1999; Peralta and Spooner 2001; Bohs 2005; Särkinen et al. 2013). The monophyletic Solanum with the inclusion of all traditional segregate genera (Cyphomandra Mart. ex Sendtn., Bohs 1995; Lycopersicon Mill.,Spooner et al. 1993; Normania Lowe, and Triguera Cav., Bohs and Olmstead 2001) is one of the ten most species-rich genera of angiosperms (Frodin 2004; see also Solanaceae Source, http://www.solanaceaesource.org). It contains several crops of economic importance in addition to the tomato, such as the potato (S. tuberosum L.) and the aubergine or eggplant (S. melongena L.), as well as other minor crops (naranjilla, S. quitoense Lam.; tamarillo or tree tomato, S. betaceum Cav. and pepino, S. muricatum Aiton). The majority of taxonomists as well as most plant breeders and other users have accepted the re-integration of 
tomatoes to Solanum (e.g., Caicedo and Schaal 2004; Fridman et al. 2004; Schauer et al. 2005; Mueller et al. 2009; Tomato Genome Consortium 2012; see also http://tgrc.ucdavis.edu/key.html). The tomato and all of its wild relatives were treated in a taxonomic monograph by Peralta et al. (2008).

The tomatoes and their close relatives are easily distinguished from any other group of Solanum species by their bright yellow flowers and pinnate or pinnatifid, non-spiny leaves; the only other species in the genus with bright yellow flowers are S. rostratum Dunal, a spiny member of sect. Androceras (Nutt.) Whalen of the Leptostemonum clade (Whalen 1979) and S. huayavillense Del Vitto, a member of the Morelloid clade (Barboza et al. 2013). Here we provide a brief review of the history of generic classification of the tomatoes and their wild relatives, species diversity and relationships amongst wild tomatoes, the position of the tomato in the Solanaceae and timing of relevant diversification events in the family and review the history of tomato introduction from its native range to a worldwide distribution as a cultivated plant.

\section{Generic position of the tomato and its relatives}

The system of giving plants a genus and species name began with Linnaeus in the first edition of Species Plantarum (1753); before that, plant names were long sentences (polynomials) in Latin that described the plant and distinguished it from others. In his first edition of The Gardener's Dictionary (Miller 1731) Philip Miller, the English botanist and curator of the Chelsea Physic Garden, used the generic name Lycopersicon meaning "wolf peach", a term previously coined by Tournefort (1694), and included a number of taxa with multilocular fruits ("roundish, soft, fleshy Fruit, which is divided into several Cells, wherein are contain'd many flat Seeds"), all color variants of the cultivated tomato (S. lycopersicum). In this same work, Miller also recognized Solanum, and included within it the eggplant as "Solanum Americanum, spinosum, foliis Melongenae, fructu mammoro" and the potato as "Solanum tuberosum, esculentum" (Miller 1731). His definition of Lycopersicon was confined to plants we would today recognize as cultivars of $S$. lycopersicum, the cultivated tomato.

In Species Plantarum, Linnaeus (1753) classified tomatoes in the genus Solanum, and described S. lycopersicum and S. peruvianum. The French botanist Adrian de Jussieu (1789), in his classification, also included tomatoes in Solanum. Miller (1754), however, continued to use both the generic name Lycopersicon and polynomial nomenclature in the abridged 4th edition of The Gardener's Dictionary. He expanded his definition of Lycopersicon by including "Lycopersicon radice tuberose, esculentum" (the potato) within it, using the following reasoning (Miller 1754): "This Plant was always ranged in the Genus of Solanum, or Nightshade, and is now brought under that Title by Dr. Linnaeus; but as Lycopersicon has now been establish'd as a distinct Genus, on account of the Fruit being divided into several Cells, by intermediate Partitions, and as the Fruit of this Plant [the potato] exactly agrees with the Characters of the other species of this Genus, I have inserted it here." 
The editor of the posthumously published edition of The Gardener's and Botanist's Dictionary (Miller 1807), Thomas Martyn, merged Lycopersicon and Solanum, and recognized all Miller's species as members of Solanum. Miller (1754) did not recognize the tomatoes by their elongate anther cones, used by later authors (e.g., D'Arcy 1972; Nee 1999; Hunziker 2001) to justify the segregation of the genus Lycopersicon, but instead, based his genus on fruit characters.

A number of classical and $20^{\text {th }}$ century authors have recognized the genus Lycopersicon mainly based on the anther morphology (e.g., Dunal 1813, 1852; Bentham and Hooker 1873; Müller 1940; Luckwill 1943; Correll 1958; D’Arcy 1972, 1987, 1991; Hunziker 1979, 2001; Rick 1979, 1988; Child 1990; Rick et al. 1990; Symon 1981, 1985; Hawkes 1990), but others continued to recognize the tomatoes as members of the genus Solanum (MacBride 1962; Seithe 1962; Heine 1976; Fosberg 1987). Today, tomatoes are widely accepted as members of the large and diverse genus Solanum, based on the results of both morphological and molecular analyses (see Peralta et al. 2008 for details).

\section{Species diversity and relationships of wild tomato relatives}

Solanum sect. Lycopersicon consists of 13 closely related taxa; the cultivated tomato, Solanum lycopersicum, which exists only as a domesticated or feral plant (Peralta et al. 2008), and 12 wild species (Table 1): Solanum arcanum, S. cheesmaniae, S. chilense, S. chmielewskii, S. corneliomulleri, S. galapagense, S. habrochaites, S. huaylasense, S. neorickii, S. pennellii, S. peruvianum, S. pimpinellifolium (Peralta et al. 2005; Spooner et al. 2005; Peralta et al. 2008). All of the wild species of section Lycopersicon occur on the western slopes of the Andes in dry desert or pre-desert environments (Figs $1 \& 2$; for distributions and environments of all species see Table 1). Four species have been segregated from the green-fruited species $S$. peruvianum sensu lato (s.1.); two of them, S. arcanum and S. huaylasense were described as new (Peralta et al. 2005) from Peru, while the other two, S. peruvianum and S. corneliomulleri had already been named by Linnaeus (1753) and MacBride (1962), respectively. In addition, S. galapagense, a yellow-to orange-fruited plant, was segregated from $S$. cheesmaniae; both species are endemic to the Galápagos Islands (Darwin et al. 2003). Lucatti et al. (2013) have suggested that S. galapagense and S. cheesmaniae should be considered conspecific but we think the morphological and combined molecular evidence argues against the lumping of these taxa; this will only obscure the useful differences already seen and used by plant breeders from these two taxa at whatever rank they are recognized (Grandillo et al. 2011). Peralta et al. (2008) put these 12 species into three informal species groups ('Arcanum', 'Eriopersicon' and 'Neolycopersicon', see Table 1) based on a combination of morphological and molecular analyses. All members of sect. Lycopersicon are diploid $(2 n=24)$ (Peralta and Spooner 2001; Nesbitt and Tanksley 2002), characterized by a high degree of genomic synteny (Chetelat and Ji 2007; Stack et al. 2009; TGC 2012), and are to some degree intercrossable (Taylor 1986). Non- 
phylogenetic schemes (Müller 1940; Luckwill 1943; Rick 1979) for the relationships of tomatoes and their wild relatives have been treated in detail by Peralta et al. (2008), so we will not treat them here.

Two other sets of species complete the tomato wild relatives in the broad sense (Table 1). Solanum sect. Juglandifolia contains the two woody tomato-like nightshades S. ochranthum and S. juglandifolium. These two species are partially sympatric and they are morphologically similar, both being woody perennials with rampant, liana-like stems up to $30 \mathrm{~m}$ in length (Correll 1962; Rick 1988; Peralta et al. 2008). Based on evidence from molecular sequence data (Peralta et al. 2008) sect. Juglandifolia is the sister group of the wild tomatoes in the strict sense. Sister to both groups is Solanum sect. Lycopersicoides, comprising the allopatric sister species $S$. lycopersicoides and $S$. sitiens. These four tomato-like nightshade species have in common several morphological features that make them intermediate between tomato and potato (Rick 1988; Stommel 2001; Smith and Peralta 2002). Tomato-like morphological characters that together differentiate them from most of other Solanum species include yellow corollas, pedicels articulated above the base, pinnately segmented non-prickly leaves, and lack of tubers (Correll 1962; Rick 1988). These four allied outgroup species are diploids $(2 n=24)$, but strong reproductive barriers isolate them from the core tomato group (Rick 1988; Correll 1962; Child 1990; Stommel 2001; Smith and Peralta 2002; Grandillo et al. 2011). Overall, crosses between the cultivated tomato and all but two (S. ochranthum and $S$. juglandifolium) of these wild species are possible, although with varying degrees of difficulty (Rick 1979; Rick and Chetelat 1995; Pertuzé et al. 2003; Grandillo et al. 2011). Although, using special techniques, introgression lines have been developed between S. lycopersicoides and $S$. lycopersicum (Chetalat et al. 1998, Canady et al. 2006). These have been useful in the elaboration of genetic maps (Chetelat and Meglic 2000), and for the understanding of cold, pest, and pathogen resistances (Davis et al. 2009).

Cladistic and phenetic studies of species boundaries and relationships within the tomatoes and all their wild relatives have used a combination of molecular and morphological data (Palmer and Zamir 1982; Spooner et al. 1993; McClean and Hanson 1986; Miller and Tanksley 1990; Breto et al. 1993; Marshall et al. 2001; Alvarez et al. 2001; Peralta and Spooner 2001; Peralta and Spooner 2005; Spooner et al. 2005; Rodriguez et al. 2010). These studies used a variety of techniques, data sets and analysis types; the reader is referred to the primary literature and to the summary of the results of these studies in Peralta et al. (2008) for further details of specific algorithms used and parameters set. The four species with brightly-colored fruits (S. cheesmaniae, S. galapagense, S. lycopersicum, $S$. pimpinellifolium) unambiguously form a closely related monophyletic group in all molecular analyses and this relationship has been suggested by all who have studied tomatoes previously (Müller 1940; Luckwill 1943; Rick 1979).

Rodriguez et al. (2010) used a set of nuclear COSII (conserved orthologous set II, Wu et al. 2006) markers to investigate the test their utility for phylogeny reconstruction in both potato and 
tomato. They did not intend to provide a definitive phylogenetic reconstruction for these groups, but instead focused on identifying markers that would be useful for future studies. Their analysis of the tomato clade, however, provided robust and well-supported hypotheses of species relationships in which the "red-orange-clade" comprising S. lycopersicum, S. pimpinellifolium, S. galapagense and S. cheesmaniae was consistently recovered with bootstrap values of $100 \%$ and posterior probabilities of 1 (Rodriguez et al. 2010). Relationships amongst the green-fruited species revealed several different topologies, suggesting different gene genealogies, and whether section Juglandifolia or Lycopersicoides is sister to the tomatoes sensu stricto was unresolved, in contrast to previous studies (see above). Their Bayesian analysis (Rodriguez et al. 2010) using 18 COSII markers showed two sister group relationships in the "red-orange clade" - S. galapagense + S. cheesmaniae and S. lycopersicum + S. pimpinellifolium. This is in accordance with geography (Darwin et al. 2003; Peralta et al. 2008) with the two Galápagos endemics most closely related to each other, and S. lycopersicum most closely related to its wild progenitor (TGC 2012). Koenig et al. (2013) recovered S. galapagense as sister to S. lycopersicum and S. pimpinellifolium sister to them (they did not include $S$. cheesmaniae), but they suggest this result stems from potential incomplete lineage sorting resulting from the extremely close relationship amongst the red- and orange-fruited species. Causse et al. (2013) also showed that repeated introgressions from wild species over the course of modern tomato breeding have resulted in extensive variation at the molecular level, perhaps obscuring the relationships of the cultivated species to one or other of its close wild relatives.

All those studying the cultivated tomato have unambiguously placed its evolutionary origins with the other tomato species with brightly colored berries. These are all species of dry, desert habitats, suggesting there is much genetic variation yet to mine in the very close relatives of $S$. lycopersicum to help tomatoes deal with environmental change to come.

\section{Tomatoes in the Solanaceae}

Tomato is a flagship species in the Solanaceae, and has been extensively used in studies on the evolution and development of fruit characters in particular (Lippman and Tanksley 2001; van der Knaap et al. 2002; Seymour et al. 2013). The Solanaceae themselves are members of the derived Asterid Clade of flowering plants (Angiosperm Phylogeny Group 2009) and molecular dating analyses coupled with fossil evidence suggests they arose just after the Cretaceous/Tertiary boundary, approximately 59 Million years ago (Bell et al. 2010) to ca. 49 Million years ago (Mya; 46.2-53.7 Mya) (Särkinen et al. 2013; see Fig. 2). Fossils available for stratigraphic calibration of the phylogenetic tree of the family are few (Särkinen et al. 2013) and all dates presented here must be considered minimum ages; it may be that older fossils are found that change the absolute, but not relative, ages of the clades mentioned here. 
Solanum lycopersicum belongs to the large clade Solanoideae (sometimes defined as a subfamily) whose members possess berries as a fruit type (with some modifications, see Knapp 2002). The stem age of the Solanoideae is estimated at ca. 21 Mya (19.0-23.3 Mya), around the same time that many of the major clades within the family began to diversify rapidly (Särkinen et al. 2013). Solanum itself has a stem age of ca. 17 Mya (14.5-17.7 Mya) and a crown age of ca. 15.5 Mya (13.317.5 Mya, see Fig. 1). Stem and crown ages differ due to differential inclusion of putative common ancestors (extinct taxa) in the group to be analysed (see Baum and Smith 2012). This hyper-diverse genus with its more than 1000 species (see Knapp et al. 2004) is relatively young and the start of its diversification occurred in the mid-Miocene.

The tomato (S. lycopersicum) and its relatives belong to Särkinen et al.'s (2013) Solanum Clade I, and within that to the Potato clade (see Fig. 2), whose stem age was calculated at ca. 14.3 Mya (12.5-16.3 Mya), with the tomato and its relatives diverging from the potatoes (section Petota) at ca. 8 Mya (6.6-9/9 Mya). Within the tomato clade in the strict sense (excluding sections Juglandifolia and Lycopersicoides) species diversification was calculated to have a minimum age of ca. 2 Mya (1.22.6 Mya). The cultivated tomato itself belongs to a very recently derived group within the clade and is not a wild species, but instead is a domesticated plant derived from its wild progenitor, $S$.

pimpinellifolium, by humans.

\section{Tomatoes travelling}

The origins of crop plants can be difficult to decipher, due at least in part to human transport and use around the world with the globalization that began in the $16^{\text {th }}$ century when Europeans first colonized the New World (Mann 2011). Even modern molecular tools can fail to unambiguously resolve origins, especially in groups like tomatoes, where spread has been global and wild species have been extensively used in breeding (Grandillo et al. 2011). How and when Solanum lycopersicum was first brought from the Americas to Europe has been debated since the late $19^{\text {th }}$ century (Candolle 1886; Jenkins 1948). The earliest description in the European botanical literature of a tomato dates from the the $16^{\text {th }}$ century in Pietro Andrea Matthioli's (Latinized as Petrus Andrea Matthiolus and sometimes also written as Mattioli) Italian-language commentary upon the work of the $1^{\text {st }}$ century Greek botanist Dioscorides of Anazarbos (Matthioli 1544). Tomatoes were classified and identified by comparison with plants already known in Europe and from classical Greek references, and, following this tradition, Matthioli (1544) described tomatoes in his section “Della Mandragorae,"(On Mandrakes) as: "Portansi à i tempi nostri d'un'altra spetie in Italia stiacciante come le mele rose, \& fatte a spicci, de color prima verdi \& come son mature, di color d'oro, lequali pur si mangiano nel medesmo modo" (Another species has been brought to Italy in our time, flattened like the "mele rose" [variety of apple] and segmented, green at first and when ripe of a golden color, which is eaten in the 
same manner). Most probably the oldest illustration of tomatoes is a watercolour part of the unpublished manuscript of Leonard Fuchs (see frontispiece of Peralta et al. 2008), and it is considered a "chimera" since represent in one plant fruits of different shapes and colours (round, flat, segmented, red and yellow ) and even green fruits with strips that might correspond to a wild species. This painting demonstrates that various different types of tomatoes (perhaps even wild species) were known in Europe by mid- $16^{\text {th }}$ century. The earliest published illustration of a tomato is a rather crude woodcut of a plant with 8-parted flowers and fascinated fruits in Dodoens' herbal (1554) published in the Netherlands. Contemporaneous published illustrations of tomatoes in the $16^{\text {th }}$ and $17^{\text {th }}$ century literature (see Fig. 3) all depict plants with large, fascinated flowers and multi-locular fruit, clearly showing that tomatoes came to Europe not as small-fruited wild species, but as domesticated, largefruited plants. These early introductions were said to have yellow (Matthioli 1544; Besler 1613) or red (Besler 1613) fruits.

Candolle (1886) suggested the tomato was introduced from Peru for both historical and botanical reasons, and subsequent workers on the group (Müller 1940; Luckwill 1943). Jenkins (1948) suggested that Mexico was the area from which the plants were introduced to Europe, based mostly on linguistic (the Nahuatl name for S. lycopersicum is 'tomatl', very like tomato) evidence and the lack of archaeological or linguistic evidence for any domestication in South America. Peralta and Spooner (2007) considered the origins for the cultivated tomato to be uncertain, and concluded that evidence is inconclusive regarding either a Mexican or a Peruvian initial site of domestication. Recent work with high density molecular markers has helped to shed light on some aspects of the story (see below).

Small-fruited cherry tomatoes were considered to be the wild progenitors of S. lycopersicum (Candolle 1886; Müller 1940; Luckwill 1943; Rick and Holle 1990); these small fruited plants are otherwise morphologically nested within the variation of the cultivated tomato and they are often seen growing in what appear to be wild conditions. Nesbitt and Tanksley (2001), however, suggested that many of these plants with small fruits were the results of admixtures with the wild species, $S$. pimpinellifolium. Molecular analyses of SNPs in a large collection of small-fruited tomatoes (Ranc et al. 2008) showed that cherry-type tomatoes were a complex mixture of S. pimpinellifolium and $S$. lycopersicum and did not form a distinct, recognisable group either based on morphology or molecules. Blanca et al. (2013) used the SOLCap platform to analyse a different set of small and large fruited tomatoes from both germplasm collections and wild origin. They found that a set of Andean accessions could be distinguished from both S. pimpinellifolium and S. lycopersicum, but that these plants did not all have small fruits. Accessions from the eastern slopes of the Andes in Ecuador and Peru were suggested to be early cultivars, with Mesoamerican accessions also distinct from those found elsewhere in the world. Blanca et al. (2013) hypothesize that the plants from Ecuador and Peru represent early domesticates, pre-breeding populations, and that the tomato was truly developed as a cultivated plant in Mexico and Mesoamerica after being taken there in pre-Columbian times. 
European heritage varieties show more molecular similarity to Mesoamerican accessions than to South American ones. The similarity of climate in Mexico and the European Mediterranean may have contributed to the ease of introduction of the tomato post-1520.

Blanca et al. (2013) distinguish these pre-breeding Andean populations at the varietal level as var. cerasiforme. This has been traditional in the tomato literature for plants of S. lycopersicum with small fruits, but we consider these plants to be the product of domestication, not of evolution by natural selection, and thus should not be named using the International Code of Nomenclature for algae, fungi, and plants (McNeill et al. 2102). In addition, Blanca et al. (2013) found that the South American accessions they identified as distinct had a wide range of fruit sizes; the accessions were better distinguished using a panel of morphological characteristics (similar to those used to distinguish S. pimpinellifolium and S. lycopersicum by Peralta et al. 2008), thus use of 'cerasiforme' could cause confusion. We suggest this distinct set of accessions be named according to the International Code of Nomenclature for Cultivated Plants (Brickell et al. 2009), as has been done for potatoes (Huáman and Spooner 2002). These conventions for naming pertain to "plants whose origin or selection is primarily due to the intentional actions of mankind" (Brickell et al. 2009). As Blanca et al. (2013) point out, further sampling of South American traditional cultivars is necessary to better understand these patterns. New collecting in the Andes where tomato pre-breeding and early domestication occurred is a priority before this diversity disappears.

Diversity within the cultivated species is likely to be well conserved ex situ; Ross (1998) cited 62,832 accessions of mainly of $S$. lycopersium maintained in gene banks around the world. A wealth of studies using isozymes (Rick and Holle 1990) and molecular markers (Williams and St. Clair 1993; Villand et al. 1998; Blanca et al. 2013) have demonstrated the high genetic diversity of landrace cultivars in South America. Nevertheless, areas close to the origin of tomatoes have not been sufficiently explored to recover these valuable genetic resources. The richness of cultural values in Andean communities is also reflected by their crop diversity, traditional cultivation and culinary practices. Small farmers developed a sustainable agriculture using ancestral land practices that are less aggressive to the environment, select crops adapted to the local conditions and maintain their own seed. Social, economic and ecological factors are affecting the conservation in situ of these genetic resources. Recently, germplasm recuperation efforts have been focused in tomato local landraces or "criollos" in Bolivia (reference) and Argentina (Peralta et al. 2008b). These landraces were incorporated in the Argentinean Vegetable Crop Germplasm Bank System (Clausen et al. 2008, http://inta.gob.ar/documentos/red-de-bancos-y-colecciones-de-germoplasma/), evaluated in the field for agronomic and fruit quality traits and their potential use in breeding programs (Peralta et al. 2008b). Traditional tomato varieties are characterized by their fruit qualities and typical flavor that consumers appreciate and now demand, although their seeds are not longer available. Recover and return of these locally adapted varieties to their original communities will contribute for a sustainable 
maintenance. In basic research, the value of these Andean accessions has been demonstrated in their contribution to understand the role of epigenetics in the determination of relevant agronomic traits (Quadrana et al. 2014). Further collections and characterization of South American traditional cultivars are necessary not only for understanding diversity patters and evolutionary relationships, but also to reveal the domestication history and elucidate the genetics of agronomic and quality traits. Recuperation, conservation and uses of local landraces, particularly those from South and Central America, in tomato breeding is essential to incorporate valuable traits, such as fruit flavor and nutritional and health beneficial components, that humans have selected for over the course of improvement of tomatoes in local situations.

\section{Summary}

The cultivated tomato, Solanum lycopersicum, is a member of the large and diverse genus Solanum of the derived Asterid family Solanaceae. It belongs to a group of 13 closely related species all of which occur in arid habitats on the west coast of South America. The tomatoes are sister to the potatoes, and began to diversify only very recently, after the rise of the Andes and the development of the arid western deserts. Tomatoes were probably brought to Europe by the Spanish from Mesoamerica, and thence distributed worldwide. Traditional, early cultivars from the eastern slopes of the Andes in Ecuador and Peru are distinct from other cultivated populations but harbor a great diversity of fruit size and are not only small-fruited. Further collecting of feral populations and local varieties from South America will contribute to elucidate the diversity and origins of the cultivated tomato, as well as to reveal the genetics of agronomic and quality traits. Efforts to conserve the variation in S. lycopersicum itself, and not only related wild species, in its area of origin are a priority. Tomato landraces, selected and adapted to their local environments, are promising genetic sources to incorporate valuable traits in cultivated varieties.

\section{Acknowledgements}

We thank Mathilde Causse for asking us to write this chapter, and all our solanaceous colleagues for years of fruitful research together, especially David M. Spooner and Lynn Bohs. SK thanks the National Science Foundation (USA) for funding under the Planetary Biodiversity Inventory programme (PBI Solanum: a worldwide treatment, DEB-0316614), the European Commission for funding under the FP6 Integrated Project EU-SOL (PL 016214) and SYNTHESYS programme (http://www.synthesys.info/ which is financed by European Community Research Infrastructure Action under the FP6 "Structuring the European Research Area" Programme); IE thanks...... 


\section{References}

Alvarez AE, van de Wiel CCM, Smulders MJM, Vosman B (2001) Use of microsatellites to evaluate genetic diversity and species relationships in the genus Lycopersicon. Theor Appl Genet 103:1283-1292

APG III (2009) An update of the Angiosperm Phylogeny Group classification for the orders and families of flowering plants: APG III. Bot J Linn Soc 161:105-121

Barboza GE, Knapp S, Särkinen TE (2013) Grupo VII. Moreloide. In: Anton AM, Zuloaga FO (eds), Barboza GE(coord) Flora Argentina vol. 13, Solanaceae, IOBDA- IMBIV, CONICET: Buenos Aires \& Córdoba, Argentina, pp 231-264

Baum DA, Smith SD (2012) Tree Thinking: an introduction to phylogenetic biology. Roberts and Co., Greenwood Village, Colorado, USA

Bell CD, Soltis DE, Soltis PS (2010) The age and diversification of the angiosperms re-visited. Am J Bot 97:1296-1303

Bentham G, Hooker JD (1873) Solanaceae. Genera Plantarum 2:882-913

Besler B (1613) Hortus eystettensis. Published by the author, Nuremberg, Germany

Blanca J, Cañizares J, Cordero L, Pascual L, Diez MJ, Nuez F (2013) Variation revealed by SNP genotyping and morphology provides insight into the origin of the tomato. PLoS ONE 7(10):e48198

Bohs L (1995) Transfer of Cyphomandra (Solanaceae) and its species to Solanum. Taxon 44:583-587

Bohs L (2005) Major clades in Solanum based on ndhF sequences. In: Keating RC, Hollowell VC, Croat TB (eds) A Festschrift for William G. D’Arcy: the legacy of a taxonomist. Monographs in Systematic Botany from the Missouri Botanical Garden, vol 104. Missouri Botanical Garden Press, St. Louis, MO, USA, pp 27-49

Bohs L, Olmstead RG (1997) Phylogenetic relationships in Solanum (Solanaceae) based on ndhF sequences. Syst Bot 22:5-17

Bohs L, Olmstead RG (1999) Solanum phylogeny inferred from chloroplast DNAsequence data. In: Nee M, Symon DE, Lester RN, Jessop JP (eds) Solanaceae IV: advances in biology and utilization. Royal Botanic Gardens, Kew, UK, pp 97-110

Bohs L, Olmstead RG (2001) A reassessment of Normania and Triguera (Solanaceae). Plant Syst Evol 228:33-48

Bretó MP, Asins MJ, Carbonell EA (1993) Genetic variability in Lycopersicon species and their genetic relationships. Theor Appl Genet 86:113-120

Brickell CD, Alexander C, David JC, Hetterscheid WLA, Leslie AC, Malecot V, Jin XB, Cubey JJ (2009) International Code of Nomenclature for Cultivated Plants (ICNCP or Cultivated Plant Code) incorporating the Rules and Recommendations for naming plants in cultivation. Eighth 
Edition. Adopted by the International Union of Biological Sciences International Commission for the Nomenclature of Cultivated Plants. Regnum Vegetabile 151; Scripta Horticulturae 10. International Society for Horticultural Science, Leuven, Belgium

Caicedo AL, Schaal BA (2004) Population structure and phylogeography of Solanum pimpinellifolium inferred from a nuclear gene. Mol Ecol 13:1871-1882

Candolle, ALPP de (1886) Origin of cultivated plants, 2d ed. D. Appleton, New York, USA (1959 reprint; Hafner Publishing Company, New York, USA)

Canady, M.A, Y. Ji, and R.T. Chetelat (2006). Homeologous recombination in Solanum lycopersicodes introgression lines of cultivated tomato. Genetics 174: 1775-1778.

Causse M, Desplat N, Pascual L, Le Paslier M-C, Sauvage C, Bauchet G, Bérard A, Bounon R, Tchoumakov M, Brunel D, Bouchet J-P (2013) Whole genome resequencing in tomato reveals variation associated with introgression and breeding events. BMC Genom 14:791

Chetelat RT, Rick CM, Cisneros P, Alpert KB, DeVerna JW (1998). Identification, transmission, and cytological behavior of Solanum lycopersicoides Dun. monosomic alien addition lines in tomato (Lycopersicon esculentum Mill.). Genome 41:40-50

Chetelat RT, Meglic Y (2000) Molecular mapping of chromosome segments introgressed from Solanum lycopersicoides into cultivated tomato (Lycopersicon esculentum). Theor. Appl. Genet. 100: 232-241

Chetelat RT, Ji Y (2007) Cytogenetics and evolution. In: Razdan MK, Mattoo AK (eds) Genetic improvement of solanaceous crops, vol 2, Tomato. Science, Enfield, NJ, USA, pp 77-112

Child A (1990) A synopsis of Solanum subgenus Potatoe (G. Don) D'Arcy section Tuberarium (Dunal) Bitter (s.1.). Feddes Rep 101:209-235

Clausen AM, Ferrer ME, Formica ME. 2008. Situación de los recursos Fitogenéticos en la Argentina. II Informe Nacional 1996 - 2006. Publicaciones Regionales. Ediciones INTA. Correll DS (1958) A new species and some nomenclatural changes in Solanum section Tuberarium. Madroño 14:232-236

Davis J, Yu D, Evans W, Gokirmak T, Chetelat RT, Stotz HU (2009) Mapping of loci from Solanum lycopersicoides conferring resistance or susceptibility to Botrytis cinerea in tomato. Theor Appl Genet 119:305-314

D’Arcy WG (1972) Solanaceae studies II: typification of subdivisions of Solanum. Ann MO Bot Gard $59: 262-278$

D’Arcy WG (1987) The circumscription of Lycopersicon. Solanaceae Newsl 2:60-61

D’ArcyWG (1991) The Solanaceae since 1976, with a review of its biogeography. In: Hawkes JG, Lester RN, Nee M, Estrada N (eds) Solanaceae III: taxonomy, chemistry, evolution. Royal Botanic Gardens, Kew, UK, pp 75-137

Darwin SC, Knapp S, Peralta IE (2003) Taxonomy of tomatoes in the Galapagos Islands: native and introduced species of Solanum section Lycopersicon (Solanaceae). Syst Biodivers 12:29-53 
Dunal MF (1813) Histoire naturelle, médicale et économique des Solanum et des genres qui ont été confundus avec eux. Montpellier, France

Dunal MF (1852) Solanaceae. In: De Candolle AP (ed) Prodromus systematis naturalis regni vegetabilis. 13:450

Fosberg FR (1987) New nomenclatural combinations for Galapagos plant species. Phytologia 62:181183

Fridman E, Carrari F, Liu YS, Fernie AR, Zamir D (2004) Zooming in on a quantitative trait for tomato yield using interspecific introgressions. Science 305:1786-1789

Frodin D (2004) History and concepts of big plant genera. Taxon 53:753-776

Grandillo S, Chetelat R, Knapp S, Spooner D, Peralta, I, Cammareri M, Perez O, Tripodi P, Termolino P, Chuisano ML, Ercolano MR, Frusciante L, Monti L, Pignone D (2011) 9. Solanum sect. Lycopersicon. In: Kole C (ed.) Wild crop relatives: genomics and breeding resources. Volume 5 - Vegetables. Springer Verlag, Heidelberg, Germany, pp 129-216 Hawkes JG (1990) The potato: evolution biodiversity and genetic resources. Belhaven, London, UK Heine H (1976) Flora de la Nouvelle Caledonie, vol 7. Museum National D’Histoire Naturelle, Paris, France

Huamán Z, Spooner DM (2002) Reclassification of landrace populations of cultivated potatoes (Solanum sect. Petota). Am J Bot 89: 947-965

Hunziker AT (1979) South American Solanaceae: a synoptic survey. In: Hawkes JG, Lester RN, Skelding AD (eds) The biology and taxonomy of Solanaceae. Academic, London, UK, pp 4985

Hunziker AT (2001) Genera Solanacearum, the genera of Solanaceae illustrated arranged according to a new system. ARG Gantner, Ruggell, Germany

Jenkins JA (1948) The origin of the cultivated tomato. Econ Bot 2:379-392

Jussieu AL (1789) Genera plantarum. Herissant V \& Barrios T, Paris, France

Knapp S (2002) Solanum section Geminata. Fl Neotrop 84: 1-405

Knapp S, Bohs L, Nee M, Spooner DM (2004) Solanaceae: a model for linking genomics and biodiversity. Comp Funct Genom 5:285-291

Koenig D, Jimenez-Gómez JM, Kimura S, Fulop D, Chitwood DH, Headland LR, Kumar R, Covington MF, Kumar Devisetty U, Tat AV, Tohge T, Bolger A, Schneeberger K, Ossowski S, Lanz C, Xiong G, Taylor-Teeples, M, Brady SM, Pauly M, Weigel D, Usadel B, Fernie AR, Peng J, Sinha N, Maloof JN (2013) Comparative transcriptomics reveals patterns of selection in domesticated and wild tomato. Proc Natl Acad Sci USA

Linnaeus C (1753) Species plantarum, 1st edn. L. Salvius, Stockholm, Sweden

Lippman Z, Tanksley SD (2001) Dissecting the genetic pathway to extreme fruit size in tomato using a cross between the small-fruited wild species Lycopersicon pimpinellifolium and $L$. esculentum var. Giant Heirloom. Genetics 158:413-422 
Lucatti AF, van Heusden AW, de Vos RCH, Visser RGF, Vosman B (2013) Differences in insect resistance between tomato species endemic to the Galapagos islands. BMC Evol Biol 13:175

Luckwill LC (1943) The genus Lycopersicon: an historical, biological, and taxonomical survey of the wild and cultivated tomatoes. Aberdeen Univ Stud 120:1-44

Macbride JF (1962) Solanaceae. In: Flora of Peru. Field Mus Nat Hist Bot Ser 13:3-267

Marshall JA, Knapp S, Davey MR, Power JB, Cocking EC, Bennett MD, Cox AV (2001) Molecular systematics of Solanum section Lycopersicum (Lycopersicon) using the nuclear ITS rDNA region. Theor Appl Genet 103:1216-1222

McClean PE, Hanson MR (1986) Mitochondrial DNA sequence divergence among Lycopersicon and related Solanum species. Genetics 112:649-667

McNeill J, Barrie FR, Buck WR, Demoulin V, Greuter W, Hawksworth DL, Herendeen PS, Knapp S, Marhold K, Prado J, Prud'homme van Reine WF, Smith GF, Wiersema JH, Turland NJ (2012) International Code of Nomenclature for algae, fungi, and plants (Melbourne Code). Regnum Vegetabile 154. Koelz Scientific Books, Königstein, Germany

Miller JC, Tanksley SD (1990) RFLP analysis of phylogenetic relationships and genetic variation in the genus Lycopersicon. Theor Appl Genet 80:437-448

Miller P (1731) The Gardener's dictionary, 1st edn. John and Francis, Rivington, London, UK Miller P (1754) The Gardener's dictionary, Abridged 4th edn. John and James. Rivington, London, UK

Mueller LA, Tanksley SD, Giovannoni JJ, van Eck J, Stack S, Choi D, Kim BD, Chen M, Cheng Z, Li C, Ling H, Xue Y, Seymour G, Bishop G, Bryan G, Sharma R, Khurana J, Tyagi A, Chattopadhyay D, Singh NK, Stiekema W, Lindhout P, Jesse T, Lankhorst RK, Bouzayen M, Shibata D, Tabata S, Granell A, Botella MA, Giuliano G, Frusciante L, Causse M, Zamir D (2005b) The tomato sequencing project, the first cornerstone of the international Solanaceae project (SOL). Comp Funct Genom 6(3):153-158

Müller CH (1940) A revision of the genus Lycopersicon. USDA Misc Publ 382:1-28

Nee M (1999) A synopsis of Solanum in the New World. In: Nee M, Symon DE, Lester RN, Jessop JP (eds) Solanaceae IV: advances in biology and utilization. Royal Botanic Gardens, Kew, Richmond, Surrey, UK, pp 285-333

Nesbitt TC, Tanksley SD (2002) Comparative sequencing in the genus Lycopersicon: implications for the evolution of fruit size in the domestication of cultivated tomatoes. Genetics 162:365-379

Olmstead RG, Palmer JD (1997) Implications for phylogeny, classification, and biogeography of Solanum from cpDNA restriction site variation. Syst Bot 22:19-29

Olmstead RG, Sweere JA, Spangler RE, Bohs L, Palmer JD (1999) Phylogeny and provisional classification of the Solanaceae based on chloroplast DNA. In: Nee M, Symon DE, Lester RN, Jessop JP (eds) Solanaceae IV: advances in biology and utilization. Royal Botanic Gardens, Kew, UK, pp 111-137 
Palmer JD, Zamir D (1982) Chloroplast DNA evolution and phylogenetic relationships in Lycopersicon. Proc Natl Acad Sci USA 79:5006-5010

Peralta IE, Spooner DM (2001) Granule-Bound Starch Synthase (GBSSI) gene phylogeny of wild tomatoes (Solanum L. section Lycopersicon [Mill.] Wettst. subsection Lycopersicon). Amer J Bot 88:1888-1902

Peralta IE, Knapp S, Spooner DM (2005) New species of wild tomatoes (Solanum section Lycopersicon: Solanaceae) from Northern Peru. Syst Bot 30(2):424-434

Peralta IE, Spooner DM (2005) Morphological characterization and Relationships of wild tomatoes (Solanum L. Section Lycopersicon [Mill.] Wettst. Subsection Lycopersicon). Monograph in Systematic Botany from the Missouri Botanical Garden 104:227-257.

Peralta IE, Knapp S, Spooner DM (2006) Nomenclature for Wild and Cultivated Tomatoes. Feature Article. Report of the Tomato Genetics Cooperative Volume 56:6-12

Peralta IE, Spooner DM (2007) History, origin and early cultivation of tomato (Solanaceae). In: Razdan MK, Mattoo AK (eds) Genetic improvement of Solanaceous crops, vol 2, tomato. Science, Enfield, NH, USA, pp 1-27

Peralta IE, Spooner DM, Knapp S (2008a) Taxonomy of wild tomatoes and their relatives (Solanum sections Lycopersicoides, Juglandifolia, Lycopersicon; Solanaceae). Syst Bot Monogr 84:1186

Peralta IE, Makuch M, García Lampasona S, Occhiuto PN, Asprelli PD, Lorello IM, Togno L (2008b) Catálogo de poblaciones criollas de pimiento, tomate y zapallo colectadas en valles andinos de la Argentina. Editorial INTA, Mendoza, Argentina

Pertuzé RA, Ji Y, Chetelat RT (2002) Comparative linkage map of the Solanum lycopersicoides and S. sitiens genomes and their differentiation from tomato. Genome 45:1003-1012

Quadrana L, Almeida J, Asís R, Duffy T, Dominguez PG, Bermúdez L, ContiG, Corrêa da Silva JV, Colot V, Asurmendi S, Fernie AR, Rossi M, Peralta I, Carrari F. Natural occurring epialleles determine vitamin E accumulation in tomato fruits. Nature Comm (in press)

Ranc N, Muños S, Santoni S, Causse M (2008) A clarified position for Solanum lycopersicum var. cerasiforme in the evolutionary history of tomatoes (Solanaceae). BMC Plant Biol 8:130

Rick CM (1979) Biosystematic studies in Lycopersicon and closely related species of Solanum. In: Hawkes JG, Lester RN, Skelding AD (eds) The biology and taxonomy of Solanaceae, Linn Soc Symp Ser 7. Academic, New York, New York, USA, pp 667-677

Rick CM (1988) Tomato-like nightshades: affinities, autoecology, and breeders opportunities. Econ Bot 42:145-154

Rick CM, Chetelat RT (1995) Utilization of related wild species for tomato improvement. Acta Hortic 412:21-38

Rick CM, Holle M (1990) Andean Lycopersicon esculentum var cerasiforme genetic variation and its evolutionary significance. Econ Bot 43(3Suppl.):69-78 
Rick CM, Laterrot H, Philouze J (1990) A revised key for the Lycopersicon species. Tomato Genet Coop Rep 40:31

Rodriguez F, Wu F, Ané C, Tanksley S, Spooner DM (2010) Do potatoes and tomatoes have a single evolutionary history, and what proportion of the genome supports this history? BMC Evol Biol 9:191

Ross RJ (1998) Review paper: global genetic resources of vegetables. Plant Var Seeds 11:39-60

Särkinen T, Bohs L, Olmstead RG, Knapp S (2013) A phylogenetic framework for the evolutionary study of the nightshades (Solanaceae): a dated 1000-tip tree. BMC Evol Biol 13:214

Schauer N, Semel Y, Roessner U, Gur A, Balbo I, Carrari F, Pleban T, Perez-Melis A, Bruedigam C, Kopka J, Willmitzer L, Zamir D, Fernie AR (2006) Comprehensive metabolic profiling and phenotyping of interspecific introgression lines for tomato improvement. Nat Biotechnol 24:447-454

Seithe A (1962) Die Haararten der Gattung Solanum L. und ihre taxonomische Verwertung. Bot Jahrb Syst 81:261-336

Seymour G, Ostergaard L, Chapman NH, Knapp S, Martin C (2013) Fruit ripening and development. Ann Rev Plant Biol 64:219-241

Smith SD, Peralta IE (2002) Ecogeographic surveys as tools for analyzing potential reproductive isolating mechanisms: an example using Solanum juglandifolium Dunal, S. ochranthum Dunal, S. lycopersicoides Dunal, and S. sitiens I.M. Johnston. Taxon 51:341-349

Spooner DM, Anderson GJ, Jansen RK (1993) Chloroplast DNA evidence for the interrelationships of tomatoes, potatoes, and pepinos (Solanaceae). Am J Bot 80:676-688

Spooner DM, Peralta IE, Knapp S (2005) Comparison of AFLPs to other markers for phylogenetic inference in wild tomatoes [Solanum L. section Lycopersicon (Mill.) Wettst. subsection Lycopersicon]. Taxon 54:43-61.

Stack SM, Covey PA, Anderson LK, Bedinger PA (2009) Cytogenetic characterization of species hybrids in the tomato clade. Tomato Genet Coop Rep 59:57-61

Stommel JR (2001) USDA 97L63, 97L66 and 97L97: tomato breeding lines with high fruit betacarotene content. HortScience 36:387-388

Symon DE (1981) The Solanaceous genera Browallia, Capsicum, Cestrum, Cyphomandra, Hyoscyamus, Lycopersicon, Nierembergia, Physalis, Petunia, Salpichroa, Withania, naturalized in Australia. J Adelaide Bot Gard 3:133-166

Symon DE (1985) The Solanaceae of New Guinea. J Adelaide Bot Gard 8:1-177

Taylor IB (1986) Biosystematics of the tomato. In: Atherton JG, Rudich J (eds) The tomato crop: a scientific basis for improvement. Chapman and Hall, London, UK, pp 1-34

Tomato Genome Consortium (2012) The tomato genome sequence provides insights into fleshy fruit evolution. Nature 485:635-641

Tournefort J. P. de (1694) Éléments de Botanique. Imprimerie Royale, Paris, France. 
Villand J, Skroch PW, Lai T, Hanson P, Kuo CG, Nienhuis J (1998) Genetic variation among tomato accessions from primary and secondary centers of diversity. Crop Sci 38:1339-1347

Van der Knaap E, Lippman ZB, Tanksley SD (2002) Extremely elongated tomato fruit controlled by four quantitative trait loci with epistatic interactions. Theor Appl Genet 104: 241-247

Whalen MD (1979) Taxonomy of Solanum section Androceras. Gentes Herb 11:359-426

Williams CE, St. Clair DA (1993) Phenetic relationships and levels of variability detected by restriction fragment length polymorphism and random amplified polymorphic DNA analysis of cultivated and wild accessions of Lycopersicum esculentum. Genome 36:619-630. 
Table 1. Tomatoes and their wild relatives (Peralta et al. 2008 'Lycopersicon group' corresponds to the red- and orange-fruited species). For further details of crossability and other biological parameters of wild tomatoes see Grandillo et al. (2011).

\begin{tabular}{|c|c|c|c|}
\hline Species & Distribution & $\begin{array}{l}\text { Habitat;(elevational } \\
\text { range }\end{array}$ & $\begin{array}{l}\text { Section according to } \\
\text { Peralta et al. (2008) }\end{array}$ \\
\hline $\begin{array}{l}\text { Solanum arcanum } \\
\text { Peralta }\end{array}$ & Northern Peru & $\begin{array}{l}\text { Dry inter-Andean } \\
\text { valleys and in coastal } \\
\text { lomas (seasonal fog- } \\
\text { drenched habitats); } \\
100-4000 \mathrm{~m}\end{array}$ & $\begin{array}{l}\text { Lycopersicon } \\
\text { 'Arcanum group' }\end{array}$ \\
\hline $\begin{array}{l}\text { Solanum cheesmaniae } \\
\text { (L.Riley) Fosberg }\end{array}$ & Galápagos Islands & $\begin{array}{l}\text { Dry, open, rocky } \\
\text { slopes; sea level-1300 } \\
\text { m }\end{array}$ & $\begin{array}{l}\text { Lycopersicon } \\
\text { 'Lycopersicon group' }\end{array}$ \\
\hline $\begin{array}{l}\text { Solanum chilense } \\
\text { (Dunal )Reiche }\end{array}$ & $\begin{array}{l}\text { Coastal Chile and } \\
\text { southern Peru }\end{array}$ & $\begin{array}{l}\text { Dry, open, rocky } \\
\text { slopes; sea level-4000 } \\
\text { m (B. Igic, pers. comm. } \\
\text { has suggested the } \\
\text { higher elevation plants } \\
\text { represent a new } \\
\text { species) }\end{array}$ & $\begin{array}{l}\text { Lycopersicon } \\
\text { 'Eriopersicon group' }\end{array}$ \\
\hline $\begin{array}{l}\text { Solanum chmielewskii } \\
\text { (C.M.Rick, Kesicki, } \\
\text { Fobles \& M.Holle) } \\
\text { D.M.Spooner, } \\
\text { G.J.Anderson \& } \\
\text { R.K.Jansen }\end{array}$ & $\begin{array}{l}\text { Southern Peru and } \\
\text { northern Bolivia }\end{array}$ & $\begin{array}{l}\text { Dry inter-Andean } \\
\text { valleys, usually on } \\
\text { open, rocky slopes; } \\
\text { often on roadcuts; } \\
1200-3000 \text { m }\end{array}$ & $\begin{array}{l}\text { Lycopersicon } \\
\text { 'Arcanum group' }\end{array}$ \\
\hline $\begin{array}{l}\text { Solanum } \\
\text { corneliomulleri } \\
\text { J.F.Macbr. }\end{array}$ & $\begin{array}{l}\text { Southern Peru (Lima } \\
\text { southwards) }\end{array}$ & $\begin{array}{l}\text { Dry, rocky slopes; 20- } \\
4500 \text { m (low elevation } \\
\text { populations associated } \\
\text { with landslides in } \\
\text { southern Peru) }\end{array}$ & $\begin{array}{l}\text { Lycopersicon } \\
\text { 'Eriopersicon group' }\end{array}$ \\
\hline $\begin{array}{l}\text { Solanum galapagense } \\
\text { S.C.Darwin \& Peralta }\end{array}$ & Galápagos Islands & $\begin{array}{l}\text { Dry, open, rocky } \\
\text { slopes; seashores; sea } \\
\text { level-1600 m }\end{array}$ & $\begin{array}{l}\text { Lycopersicon } \\
\text { 'Lycopersicon group' }\end{array}$ \\
\hline
\end{tabular}




\begin{tabular}{|c|c|c|c|}
\hline $\begin{array}{l}\text { Solanum habrochaites } \\
\text { S.Knapp \& } \\
\text { D.M.Spooner }\end{array}$ & $\begin{array}{l}\text { Andean Ecuador and } \\
\text { Peru }\end{array}$ & $\begin{array}{l}\text { Montane forests, dry } \\
\text { slopes and occasionally } \\
\text { coastal lomas; 10-4100 } \\
\text { m }\end{array}$ & $\begin{array}{l}\text { Lycopersicon } \\
\text { 'Eriopersicon group' }\end{array}$ \\
\hline $\begin{array}{l}\text { Solanum huaylasense } \\
\text { Peralta }\end{array}$ & $\begin{array}{l}\text { Río Santa river } \\
\text { drainage, north-central } \\
\text { Peru }\end{array}$ & $\begin{array}{l}\text { Dry, open, rocky } \\
\text { slopes; 950-3300 m }\end{array}$ & $\begin{array}{l}\text { Lycopersicon } \\
\text { 'Eriopersicon group' }\end{array}$ \\
\hline $\begin{array}{l}\text { Solanum } \\
\text { juglandifolium Dunal }\end{array}$ & $\begin{array}{l}\text { Andean Colombia, } \\
\text { Ecuador and Peru }\end{array}$ & $\begin{array}{l}\text { Montane cloud forests; } \\
1000-3200 \mathrm{~m}\end{array}$ & Juglandifolia \\
\hline $\begin{array}{l}\text { Solanum } \\
\text { lycopersicoides Dunal }\end{array}$ & $\begin{array}{l}\text { Southern Peru and } \\
\text { northern Chile }\end{array}$ & $\begin{array}{l}\text { Rocky slopes and } \\
\text { ravines; 1250-3600; }\end{array}$ & Lycopersicoides \\
\hline $\begin{array}{l}\text { Solanum lycopersicum } \\
\text { L. }\end{array}$ & $\begin{array}{l}\text { Globally cultivated } \\
\text { domesticate }\end{array}$ & $\begin{array}{l}\text { Cultivated; sea level- } \\
4000 \mathrm{~m}\end{array}$ & $\begin{array}{l}\text { Lycopersicon } \\
\text { 'Lycopersicon group' }\end{array}$ \\
\hline $\begin{array}{l}\text { Solanum neorickii } \\
\text { D.M.Spooner, } \\
\text { G.J.Anderson \& } \\
\text { R.K.Jansen }\end{array}$ & $\begin{array}{l}\text { Southern Ecuador to } \\
\text { southern Peru }\end{array}$ & $\begin{array}{l}\text { Dry inter-Andean } \\
\text { valleys; 500-3500 m }\end{array}$ & $\begin{array}{l}\text { Lycopersicon } \\
\text { 'Arcanum group' }\end{array}$ \\
\hline $\begin{array}{l}\text { Solanum ochranthum } \\
\text { Dunal }\end{array}$ & $\begin{array}{l}\text { Andean Colombia, } \\
\text { Ecuador and Peru }\end{array}$ & $\begin{array}{l}\text { Montane cloud forests; } \\
1850-4100 \mathrm{~m}\end{array}$ & Juglandifolia \\
\hline $\begin{array}{l}\text { Solanum pennellii } \\
\text { Correll }\end{array}$ & $\begin{array}{l}\text { Northern Peru to } \\
\text { northern Chile }\end{array}$ & $\begin{array}{l}\text { Dry slopes and washes, } \\
\text { usually in flat areas; } \\
\text { sea level-4100 m }\end{array}$ & $\begin{array}{l}\text { Lycopersicon } \\
\text { 'Neolycopersicon } \\
\text { group' }\end{array}$ \\
\hline $\begin{array}{l}\text { Solanum peruvianum } \\
\text { L. }\end{array}$ & $\begin{array}{l}\text { Central Peru to } \\
\text { northern Chile }\end{array}$ & $\begin{array}{l}\text { Dry coastal deserts and } \\
\text { lomas; sea level-3000 } \\
\text { m }\end{array}$ & $\begin{array}{l}\text { Lycopersicon } \\
\text { 'Eriopersicon group' }\end{array}$ \\
\hline $\begin{array}{l}\text { Solanum } \\
\text { pimpinellifolium } \mathrm{L} \text {. }\end{array}$ & $\begin{array}{l}\text { Southwestern Ecuador } \\
\text { to northern Chile } \\
\text { (many northern } \\
\text { populations in Ecuador } \\
\text { are admixture with } S \text {. } \\
\text { lycopersicum; Peralta } \\
\text { et al. 2008; Blanca et } \\
\text { al. 2013) }\end{array}$ & $\begin{array}{l}\text { Dry slopes, plains and } \\
\text { around cultivated } \\
\text { fields; sea level-3000 } \\
\text { m }\end{array}$ & $\begin{array}{l}\text { Lycopersicon } \\
\text { 'Lycopersicon group' }\end{array}$ \\
\hline $\begin{array}{l}\text { Solanum sitiens } \\
\text { I.M.Johnst. }\end{array}$ & Northern Chile & $\begin{array}{l}\text { Dry ravines and slopes } \\
\text { (hyperarid areas); } \\
2000-3500 \mathrm{~m}\end{array}$ & Lycopersicoides \\
\hline
\end{tabular}




\section{Figure legends}

Figure 1. Distribution map of tomato wild relatives

Figure 2. Dated Solanaceae phylogeny; only major clades shown with representative flowers/fruits alongside. Grey bars correspond to date ranges as seen in text. (from Särkinen et al. 2013, reproduced with permission).

Figure 3. An early wood cut illustration of Solanum lycopersicum, showing the fasciated flowers and large multi-locular fruits present in early European tomatoes. Reproduced with permission of the Library of the Natural History Museum, London.

Figure 4. A plate of landraces from South America 